\title{
JOŠ O MEĐUJEZIČNOJ HOMONIMIJI HRVATSKO-RUSKOJ I HRVATSKO-UKRAJINSKOJ ${ }^{1}$
}

$\mathrm{P}$ oznata je pojava unutar nekog jezika da postoje riječi jednake na planu izraza i različite na planu sadržaja - homonimi. Ovdje se govori o homonimnim odnosima između triju srodnih jezika: hrvatskoga, ruskog i ukrajinskog, s kojima se susreće svatko tko, kao nositelj jednoga od njih, upoznaje onaj drugi. Navode se uzroci njihove pojave i razrađuju se kao homografi i homofoni.

1. Može li se govoriti o međujezičnoj homonimiji?

Da, ali uz primjedbu da, pojednostavljeno, možemo govoriti: 1) o nesrodnim jezicima koji nisu u kontaktu, 2) o nesrodnim jezicima u kontaktu i 3) o srodnim jezicima (bez obzira na to jesu li ili nisu - iz povijesno-političkih razloga - u čestom i tijesnom kontaktu).

Međujezična homonimija u nesrodnim jezicima koji nisu u kontaktu potpuna je slučajnost (ukoliko se ne radi o riječi što bi je oba takva jezika dobila iz nekog trećeg, a koju bi preuzeli s različitim značenjem, ili bi ta različitost značenja nastala kasnije).

Međujezična homonimija u nesrodnim jezicima u kontaktu također je slučajnost, ali postoji puno veća mogućnost da se riječi međusobno preuzimaju i pritom dobivaju drugačije značenje.

Ne ulazimo u pitanje homonimije - homofonije i homografije u nesrodnim jezicima koji nisu ili koji jesu u kontaktu.

\section{O hrvatsko-ruskoj jezičnoj homonimiji}

2. Kada govorimo o međujezičnoj homonimiji u hrvatskom i ruskom jeziku, govorimo o konkretnom slučaju međujezične homonimije u srodnim jezicima.

Pođemo li od najjednostavnije definicije, da je homonimija podudaranje na planu izraza dviju (ili više) riječi različitih na planu sadržaja, moramo zaključiti: hrvatski i ruski jezik (ovakvi kakvi su sada) ne mogu imati nijedan slučaj potpune homonimije (homofonije).

Zašto?

Kada ne bi bilo drugih razloga, bila bi dovoljna činjenica da hrvatski standardni jezik (temeljen na novoštokavštini) ima sustav od četiri naglaska, tj. ima tonski naglasak (koji se

Ovaj je članak nešto izmijenjena verzija naših dvaju članaka: 1) O međujezičnoj (hrvatskosrpskoruskoj) homonimiji i 2) O međujezičnoj hrvatskosrpsko-ukrajinskoj homonimiji. Oba su objavljena u Radovima Zavoda za slavensku filologiju, prvi u br. 23, 1988., a drugi u br. 24, 1989. U prvome je od njih prvi put u stručnoj literaturi ovako razrađena pojava koja se odnosi na dva srodna slavenska jezika: hrvatski i ruski, gotovo isključivo nazivana lažni prijatelji, a koja je u njemu, uz obrazloženje - po točkama-zašto, nazvana i razmatra se kao međujezična homonimija. U drugome je od njih prvi put u stručnoj literaturi - po točkama razrađenim u prvome članku - prikazana međujezična homonimija u drugim dvama slavenskim jezicima: hrvatskom i ukrajinskom. Da bi se moglo govoriti o međujezičnoj homonimiji, u oba je članka dan kratki prikaz odnosa: hrvatskih i ruskih (standardnih) fonema, s jedne strane, te hrvatskih i ukrajinskih, s druge. 
još kombinira s postojanjem ili nepostojanjem dužine na nenaglašenom vokalu), a ruski standardni jezik ima samo jedan, dinamički naglasak. (Čak ni u najsličnijim slučajevima kada je u hrvatskom u dvosložnim riječima, s [a] u prvome slogu i na kraju, na prvome [a] kratkosilazni naglasak, na primjer: para, praćka, a u ruskom u odgovarajućim riječima (jedini dinamički) naglasak na istom slogu - nара (= pâr), прачка (= pralja), zvučno ostvarenje nije isto.)

Tonski naglasak u hrvatskom i dinamički u ruskom jeziku daju, dakle, uvijek drugačiju suprasegmentnost naglašenih vokala.

Ovome još treba dodati i, tipičnu za ruski jezik, redukciju nenaglašenih vokala (koju hrvatski standardni jezik ne poznaje). (Novoštokavski govori znaju za potpunu redukciju nenaglašenoga [i] poslije naglašenoga sloga: [vodenca / vodenjca], [šalca / šaljca] itd., gdje je u ostvarajima s [nj] i [lj] trag reduciranoga [i].)

Ako je riječ o suglasnicima, u ruskom je jeziku obvezno pojavljivanje isključivo bezvučnih suglasnika (govori se o obezvučenju zvučnih suglasnika - čak i sonornih, premda ne obvezno) na kraju iskaza (i od jedne riječi) (čega u novoštokavštini, a ni u čakavskome narječju, također nema, ali je obilježje kajkavštine), na primjer: [rok] za poк/rok i za poz/rog, [trut] za mpym/trut i za mpyd/trud; također je za sustav ruskih suglasničkih fonema tipično postojanje 15 parova nepalataliziranih i palataliziranih suglasnika (za koje se shematski može reći da su to "neumekšani + istovremena [j]-artikulacija"), što znači da je riječ o 30 suglasničkih fonema koji čine takve parove (a što je u hrvatskome zastupljeno u mnogo manjem broju parova - samo u četiri: /č/ : /ć/, /dž/ : /d/, /1/ :/l'/,/n/: /n'/, pri čemu nijedan od ovih zvukovnih ostvaraja nema pravi adekvat u ruskom), na primjer: мило/milo [m’ił $\Lambda / \partial]=$ milo, drago і мьлло/mylo [mýł $\Lambda / \partial]$ = sapun (ovdje je još prisutno i pitanje [i], [y] i problem jesu li pred nama varijante jednog fonema ili su to dva različita vokalna fonema; također treba reći da je [ł] zubno, kao u nekim hrvatskim novoštokavskim govorima, a ne alveolarno - kao u hrvatskom standardnom jeziku).

Ako - ne navevši sve razlike u ostvarajima hrvatskih i ruskih vokalnih i suglasničkih fonema - dodamo još i činjenicu da mjesto naglaska u ruskom jeziku vrlo često ne odgovara mjestu naglaska u hrvatskom - onda ćemo ponoviti istinu: ne postoji nijedan slučaj - s gledišta izgovora - potpune homonimije u hrvatskom i ruskom (standardnom) jeziku.

3. Pa ipak, zašto onda govorimo o međujezičnoj hrvatsko-ruskoj homonimiji?

Budući da je riječ o srodnim jezicima, nositelji obaju jezika posjeduju određenu mogućnost prepoznavanja, identifikacije. Razumije se da je najlakše "prepoznati” onda kada je najmanje nejednakih elemenata! (kao u navedenim riječima: para - napa, praćka - прачка, jer se rusko [č'] identificira s hrvatskim [č] ili [ć] - prema tome u kakvom je okruženju, tj. u kojoj je riječi, a nenaglašeno [a] na kraju (obiju) ruskih riječi identificira se s hrvatskim [a]; budući da je ruski dinamički naglasak na istom mjestu gdje je i kratkosilazni naglasak u odgovarajućim hrvatskim riječima, razlika u ostvarenju fonema /a/ - zbog razlike u suprasegmentnosti - nije ovdje faktor za neprepoznavanje, nego je, obrnuto, faktor za "prepoznavanje", identifikaciju).

Ta se sposobnost "prepoznavanja”, izjednačavanja s odgovarajućom riječju u vlastitom jeziku, zasniva na analogiji. Razumije se, nositelj hrvatskoga jezika propušta ruske riječi kroz 
svoje "fonološko sito", pa "prepoznaje" i ono što ne bi trebalo da "prepozna": na primjer, u nominativu jednine rusku imenicu srednjega roda вóŭcкo/vojsko "prepoznaje” isključivo kao imenicu ženskoga roda vójska (u ovom je posljednjem primjeru naš dugouzlazni naglasak) zbog redukcije krajnjeg nenaglašenog vokala. (Dakako, i nositelj ruskoga jezika propušta hrvatske riječi kroz svoje "fonološko sito", ali je u ovom smjeru "prepoznavanja" manja mogućnost za greške ovakve naravi, jer je hrvatski vokalizam "prozirniji” - nema redukciju, osim u govorima. Pa ipak, upravo navedeni primjer može poslužiti tome da pokaže kako kod nositelja ruskog jezika nastaje analogna greška: on [a] na kraju naše riječi vojska čuje kao [a] (reducirani) na kraju ruske riječi войско, pa tako hrvatsku imenicu ženskoga roda doživljava kao imenicu srednjega roda.)

Budući da se međujezična hrvatsko-ruska homonimija (i ne samo ona) ostvaruje kroz analogiziranje od strane nositelja obaju jezika (prvenstveno govorimo s gledišta nositelja hrvatskoga jezika), događa se ono što se događa uvijek kad se vrši kakva analiza jezične građe (a i analogiziranje se ostvaruje kroz analizu jezične građe): ne dolaze do istoga rezultata dva nositelja istoga jezika koji su različito obaviješteni o jezičnoj građi. Naime, bolji poznavatelj, "razumijevalac", makar i samo svojega jezika, nalazit će analogiju i tamo gdje je slabiji poznavatelj jezičnih pojava ne će uopće tražiti. Na primjer: čvrst odnos između punoglasja ( $\leftarrow$ полногласие/polnoglasie) u ruskom jeziku i (bivše) metateze u hrvatskom razlog je za "poznavatelja" jezičnih pojava da i u takvim slučajevima nalazi analogiju (na primjer, da u берег/bereg = obala "prepozna" brijeg).

Dakle, postoje riječi u oba jezika koje, praktično, svaki nositelj tih jezika doživljava, čim ih čuje, kao analogne, a postoje i riječi koje od nositelja drugoga jezika bivaju prihvaćene kao analogne nejednako, upravo stupnjevito, prema "smislu za jezik" onih što ih čuju, odnosno prema stupnju poznavanja drugoga jezika.

Cijelo se vrijeme govori o mogućnosti da se neka riječ ruskoga jezika doživi, tj. čuje kao odgovarajuća hrvatska. Riječ je dakle upravo o govoru kao izvoru za ostvarivanje međujezične hrvatsko-ruske homonimije, riječ je o homofoniji. Ali postoji još jedan izvor, na današnjem stupnju civilizacije gotovo jednako važan: pismo.

Ono je, upravo kada je riječ o međujezičnoj hrvatsko-ruskoj homonimiji, osobito važno, ponekada i važnije, i to zbog morfemskog principa (naš termin; neki ga zovu morfološki, neki fonemski) kao vodećeg principa ruskog pravopisa (formulacija toga principa: bez obzira na to što može različito zvučati, isti se morfem uvijek jednako piše). Jer upravo on čitatelju, nositelju hrvatskoga jezika, daje mogućnost da nalazi analognost i tamo gdje je u govoru ne bi mogao uočiti (i to upravo zbog spomenutih - ne svih - fonemsko-fonetskih pojava u ruskom jeziku), jer morfemski princip ruskog pravopisa umnogome približava lik ruske riječi liku analogne riječi u hrvatskom (usporedi: na pismu живот/život = trbuh, u govoru [žyvót]; na pismu столийa/stolica, u govoru [st $\Lambda$ l'íc $\Lambda / \partial]$ ). Riječ je, dakle, o homografiji.

4. I kada je riječ o homofoniji i kada je riječ o homografiji, u homonimski odnos mogu ući: a) nepromjenljive riječi, b) nepromjenljive riječi i riječ-oblici promjenljivih riječi, c) promjenljive riječi (dijelom ili u cjelini).

4.1. Ima riječi/riječ-oblika u ruskom jeziku koje ulaze u odnos homofonije, s jedne strane, i odnos homografije, s druge strane, s različitim riječima u hrvatskom jeziku.

4.2. U takvom slučaju hrvatska riječ/riječ-oblik - koja je ušla u odnos homofonije - au- 
tomatski ostvaruje odnos dvostruke homofonije i jednostruke homografije.)

4.3. a) Za nositelje hrvatskoga jezika - poznavaoce ruskoga jezika (u manjoj ili većoj

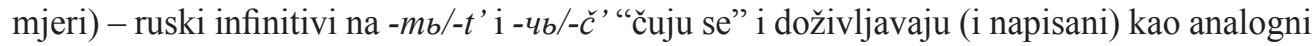
infinitivima u hrvatskom; b) oblici nominativa jedn. m. r. pridjeva u ruskom jeziku na -uŭ/ij i -bǔu/-yj "čuju se" i doživljavaju (i napisani) kao analogni određenom obliku pridjeva u nominativu jedn. m. r. u hrvatskom (doživljavanje analognosti tiče se i ostalih nominativnih oblika pridjeva; međutim, kada je riječ o obliku nominativa jedn. m. r. na -oŭ/-oj, nedovoljni poznavaoci ruskoga jezika ne doživljavaju ga kao gramatički analogan danom obliku u hrvatskom: o tome govori činjenica kako u hrvatskom izgledaju, na primjer, genitivni oblici od prezimena (pseudonima) Gorki (Горький/Gor 'kij), s jedne strane, i Tolstoj (Толстой), s druge, a također i teškoće s dekliniranjem sintagme Boljšoj teat(a)r/Большой театр); c) imenice srednjega roda u ruskom jeziku na -Hue/-nie i -Hbe/-n'e "čuju se” i doživljavaju (i napisane) kao imenice na -nje u hrvatskom; d) imenice ženskoga roda na -cmb/-st' u ruskom jeziku "čuju se" i doživljavaju (i napisane) kao imenice ženskoga roda na -st u hrvatskom (to se ne tiče ostalih imenica te deklinacije, pa dolazi do gramatičke međujezične homonimije: ruske su imenice ženskoga roda Казань,-, , Сибирь,-и, Пермь,- $и$ u hrvatskome imenice muškoga roda Kazan,-a / Kazanj,-a, Sibir,-a, Perm,-a itd.; da bi se izbjegla takva gramatička međujezična homonimija, a i kao posljedica pisanja Sibiria, nekada se upotrebljavao oblik Sibirija).

5. Pokazat ćemo primjere hrvatsko-ruske homografije prema onome što je rečeno u točkama 4.- 4.3., uz primjedbu: bit će parova koji predstavljaju potpunu homografiju s gledišta ekavskog izgovora i odgovarajućeg pisanog oblika danih riječi i nepotpunu homografiju s gledišta (i)jekavskog izgovora i odgovarajućeg pisanog oblika danih riječi.

5.1. Primjeri pomoćnih (nepromjenljivih) ruskih riječi koje čine potpune homografske parove s odgovarajućim pomoćnim hrvatskim riječima:

... а Васька слушает да ест ... (да $\mid$ da) = ... a Vaska sluša i jede ...

... не был там ... (не $\mid$ ne $)=\ldots$ nije bio tamo ...

... билет на завтра ... (на $\mid$ na $)=\ldots$ karta za sutra ...

(Primjedba: posebnu obradu zahtijevaju homonimski odnosi prijedloga.)

5.2. Primjer pomoćne (nepromjenljive) ruske riječi koja čini potpun homografski par s odgovarajućim riječ-oblikom samostalne (promjenljive) hrvatske riječi (i s nominativom jedn. imenice i s komparativnim oblikom pridjeva):

... уюке никого нет ... (уже $\mid$ uže) = ... već nikoga nета ...

(Primjedba: yжe/uže je i unutarjezični homograf : ýжe = komparativ $\mid$ yжé = čestica.)

5.3. Primjeri ishodišnih riječ-oblika samostalnih (promjenljivih) ruskih riječi koje čine potpune homografske parove s odgovarajućim riječ-oblicima hrvatskih riječi:

... глава делегации (государства) ... (глава $\mid$ glava) = ... šef delegacije (države) ...

... измена родине ... (измена $\mid$ izm(j)ena) = ... izdaja domovine ...

(Primjedba: s gledišta pisanja - potpuna "ekavska” homografija; s gledišta izgovora nepotpuna homofonija bliža (i)jekavštini.)

... новая майка ... (майка $\mid$ majka $)=$... nova majica, potkošulja ...

... чёрная мука ... (мука $\mid$ muka $)=\ldots$ сrno brašno ... 
(Primjedba: мука/muka je i unutarjezični homograf : му́ка = muka $\mid$ мукá = brašno.)

... налог на доход ... (налог $\mid$ nalog) $=$... porez na prihod ...

... каменная стена ... (стена $\mid$ st(ij)ena) = .. kameni zid ...

(Primjedba: s gledišta pisanja - potpuna "ekavska" homografija, dakako "prepoznatljiva" i s gledišta ijekavštine; ne vidi li se napisan, ovaj se ruski riječ-oblik, s obzirom na izgovor ([s't' $\square$ na]), i ne može "prepoznati” kao stijena.)

... лютый враг ... (враг | vrag) = ... ljuti neprijatelj ...

... заход солнциа ... (заход | zahod) = zalaz sunca ...

... мой жнивот ... (живот $\mid$ život) $=$ moj trbuh ...

... длинный шест ... (шест $\mid$ šest $)=\ldots$ dugačka motka ...

(Primjedba: u hrvatskome je šest samostalna, ali nepromjenljiva riječ.)

5.4. Postoji i varijanta homografskog odnosa - kada je u ruskoj riječi slovo bl (lat. y):

... река течёт быстро ... (быстро | bistro) = ... rijeka teče brzo ...

5.5. Možemo uvesti i pojam uvjetnog homografskog odnosa: primjenljiv je za slučajeve kada nam je poznat (ustaljeni) suodnos izražavanja na pismu nekih fonema u ruskom jeziku i njima odgovarajućih fonema $u$ hrvatskom, tj. uz uvjet da znamo:

a) da na mjestu slova $\varphi$ u ruskoj ćirilici (u danim riječima) u hrvatskoj latinici (u odgovarajućim riječima) nalazimo slova $\check{c} / c$, pa imamo, s jedne strane:

... видна туча ... (туча $\mid$ tuča $)=\ldots$ vidi se oblak ...

... положи на кучку ... (кучка $\mid$ kučka) = ... stavi na hrpicu/gomilicu ..., a s druge:

... там их цуелая куча ... (куча $\mid$ kuća $)=$.. tamo ih je cijela hrpa/gomila ...

b) da na mjestu slova $u$ u ruskoj ćirilici (u danim riječima) u hrvatskoj latinici (u odgovarajućim riječima) nalazimo (dva) slova: št (u srpskoj i crnogorskoj ćirilici um), pa imamo:

...большое позорище... (позорище | pozorište - u srp.) = ...velika/strašna sramota...;

c) da na mjestu slova $c m b$ u ruskoj ćirilici na kraju imenica u ruskom jeziku (već je rečeno) u hrvatskoj latinici na kraju odgovarajućih riječi nalazimo slova st, pa imamo:

... масть лошади, козыря ... (масть $\mid$ mast $)$ = ... boja konja, aduta ...;

d) da na mjestu slova нuе, ньe u ruskoj ćirilici na kraju imenica u ruskom jeziku (već je rečeno) u hrvatskoj latinici na kraju odgovarajućih riječi nalazimo nje, pa imamo:

...nечальное уединение.. (уединение | ujedinjenje) = ...tužna osamljenost/osama...

... вкусное кушанье ... (кушанье $\mid$ kušanje) $=$... ukusno jelo ...;

e) da na mjestu slova $m b$, чb u ruskoj ćirilici na kraju infinitiva u ruskom jeziku (već je rečeno) u hrvatskoj latinici na kraju infinitivnog oblika nalazimo $t i, c i$, pa imamo:

... часто шутить ... (шутить $\mid$ šutjeti / razgovorno i šutiti) = ... često se šaliti ...

... ужасно орать ... (орать $\mid$ orati) $=$... strašno/užasno se derati ...;

f) da na mjestu slova $u \check{u}$, biŭ u ruskoj ćirilici na kraju nominativnih oblika jednine m. r. pridjeva u ruskom jeziku (već je rečeno) u hrvatskoj latinici na kraju odgovarajućeg (određenog) pridjevskog oblika nalazimo $i$, pa imamo:

... красный крест ... (красный $\mid$ krasni $)=$.. crveni križ ...

... спорый мастер ... (спорый $\mid$ spori) = .. brz(i)/vješt(i) majstor ... 
6. Kao što je već rečeno (a navedeni su i razlozi za to), potpune homofonije nema: ona je uvijek - u većoj ili manjoj mjeri - uvjetna.

(Primjedba: većina primjera - potpune ili uvjetne - homografije mogla bi poslužiti i za pokazivanje postojanja homofonije. Većina, ali ne svi primjeri, zbog priličnog udaljavanja u nekim slučajevima od zvučanja odgovarajućih riječi u hrvatskom, što znači da u takvim slučajevima (pri nedovoljnom poznavanju ruskog jezika) ne dolazi do "prepoznavanja", na primjer, kako je već pokazano: стена [s't'1na].)

Ali, bez obzira na malu, manju ili veću uvjetnost, činjenica "prepoznavanja" postoji, dakle (kao što je već rečeno) postoji pojava homofonije.

7. Navodimo još neke primjere hrvatsko-ruske homonimije (od vrlo malo do izrazito uvjetnih):

... горячий пар ... (пар | par) = ... vruća para ...

... танцеевальная пара ... (пара $[$ par $\Lambda / \partial] \mid$ para $)=$.. plesni par ...

... злой рок ... (рок [rok] $\mid$ rok $)=\ldots$ zla/teška sudbina ...

... острый рог ... (рог $[\mathrm{rok}] \mid$ rok $)=$... oštar/oštri rog ...

(Primjedba: nominativni su oblici рок і рог ruski unutarjezični homofoni; oba čine međujezični homonimski par s hrvatskim nominativnim oblikom rok; poк i rok su i ćirilično-latinični homografski par.)

... pыбий жжир ... (жир [žyr] | žir) = ... riblje ulje ...

(Primjedba: жир i žir su ćirilično-latinični homografski par i - "prepoznatljivi” nepotpuni - homofonski.)

Почему ёжс ? (ёж [još] | još) = Zašto jež?

... старая прачка ... (прачка $[$ prač $\mathrm{k} \Lambda / \partial] \mid$ praćka) = ... stara pralja ...

... ягода винограда ... (ягода $[\mathrm{jag} \partial \mathrm{d} \Lambda / \partial] \mid$ jagoda) $=$ zrno/boba grožđa ...

(Primjedba: međujezični su homonimski par i ruska riječ виноград/vinograd - u hrvatskome $=$ grožđe i hrvatska riječ vinograd - u ruskome $=$ виноградник/vinogradnik.)

... вредный продукт ... (вредный [vr'ednyi] | vr(ij)edni) = .. štetni/štetan proizvod ...

(Primjedba: u [vr'ednyi] se u transkripciji na kraju bilježi ili neslogotvorni [i] ili [i].) ... зелёный берег ... (берег | brijeg) = ... zelena obala ...

(Primjedba: oni što su uočili odnos -epe- |-re-/-rije- "prepoznaju” берег kao brijeg.)

8. Većina se do sada navedenih primjera homonimije (homografije i homofonije) odnosi na ishodišne oblike promjenljivih riječi u ruskom i hrvatskom jeziku. Mi nismo navodili primjere homonimije ishodišnih i neishodišnih oblika te neishodišnih oblika međusobno, premda ih ima nemali broj (na primjer: homografi вoд/vod (gen. množ. od вoda/voda u ruskom) i vod (nom. jedn. dviju imenica u hrvatskom), homofoni ною/поји [nојu] (1. lice jedn. prezenta od hblmb$/ n y t^{\prime}$ ' = biti snužden - u ruskom) i noju (dativ jedn. od noj - u hrvatskom).

9. Kao što je već u primjedbi u točki 5.1. rečeno, da "posebnu obradu zahtijevaju homonimski odnosi prijedloga", tako ovdje dodajemo: posebnu obradu (i davanje popisa, što nismo postavili kao zadatak koji treba ostvariti u ovome članku) zahtijevaju također homo- 
nimski odnosi a) prefiksa, b) sufiksa, c) postfiksa povratnosti / morfema satelita, d) nastavaka. To su zadaće što ih nameće upravo činjenica da su hrvatski i ruski jezik srodni slavenski sintetični jezici.

10. Međujezična homonimija, osobito srodnih jezika, dakle, postoji. (Poznata je anegdota kako je nositelj hrvatskoga jezika poželio u zdravici nositelju (ili nositeljima) ruskoga jezika "krasan život”" (красный живот = crven(i) trbuh), ili kako nepoznavalac (ili loš poznavalac) ruskoga jezika - nositelj hrvatskoga jezika - na upit "Как ваша фамилия?/ Kak vaša familija?" = "Kako je vaše prezime?” veoma često odgovara: "Dobro", ili "Nisam oženjen / Nisam udana”.). Nju, homonimiju - u praksi - kontekst (u najširem značenju) može odstraniti, može ukazati na to da je posrijedi (ne dajući objašnjenje kakva upravo), a može je i podržati.

11. Kako dolazi do međujezične homonimije kada je riječ o srodnim jezicima?

Više je izvora.

Prvi je od njih stara polisemija (uz očuvanje iste tvorbene strukture).

Drugi je preuzimanje u ruskom jeziku (uz očuvanje vlastite - istočnoslavenske - varijante) staroslavenske (dakle, južnoslavenske) varijante neke riječi (na primjer, u ruskom jeziku parovi: голова/golova i глава/glava, горожанин/gогоžanin i гражданин / graždanin), pri čemu među varijantama dolazi do razdvajanja na semantičkom planu.

Treći je izvor nejednak razvoj nekadašnjih zajedničkih fonema (na primjer, izraz na ruskom плоть и кровь/plot' $i$ krov' (= tijelo i krv) može se “prepoznati” kao hrvatske riječi plot $i$ krov).

Četvrti je izvor naknadna, druga nominacija, što je povezano s novom polisemijom, pa tako jedna značenja riječi ne ulaze u homonimske parove, a druga ulaze (na primjer, drugo značenje ruske riječi $\sigma b l \kappa / b y k=$ mosni stup / stup mosta).

S tim je u vezi i polisemija (na planu slavenskih jezika, pa, prema tome, može biti stara i novija) gramatičkih morfema, što u kombinaciji dovodi do slučajeva kao što su: ruska riječ столица/stolica $=$ prijestolnica i hrvatske stolica $^{1,2}$, ruska riječ дворищуе/dvorišče = golemo dvorište i hrvatska dvorište (hrvatska riječ dvorište u ruskome je dвop/dvor).

Izvorom međujezične homonimije može još biti i primanje riječi iz drugih (neslavenskih) jezika, uz očuvanje starih za iste predmete, pri čemu dolazi do njihova razilaženja na planu stilistike (i ne samo stilistike) (na primjer: današnja standardna značenja ruskih riječi конь/kоn' і лошадь/lošad', око/оkо і глаз/glaz, pa i пёс/pёs і собака/sobaka; zanimljivo je da u polisemičnost unutar jezika ulaze uglavnom stare riječi).

Jedan je od izvora također i nejednako primanje iz stranih jezika (usporedi: ruske riječi

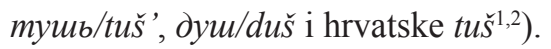

Dakako, izvor su međujezične homonimije, upravo homofonije (rečeno je: nikada potpune), kada je riječ o ruskom i hrvatskom jeziku, i nejednaka pravila distribucije fonema (usporedi: rusku riječ poz/rog i hrvatsku rok, rusku riječ ë»/ëž i hrvatsku još).

Izvor homonimije može biti i "potpuna slučajnost". Na primjer, jelo koje se u hrvatskom zove pilav u ruskom se jeziku zove nлов/plov (i kao jelo i kao naziv došlo je od "trećih" naroda), pa ta ruska imenica i hrvatska glagolska imenica plov čine homonimski par. 
12. Hrvatsko-ruska međujezična homonimija pojava je s kojom se suočava svaki nositelj hrvatskoga jezika kad uči ruski jezik i, obrnuto, svaki nositelj ruskoga jezika kad želi naučiti hrvatski. Njezinim se osmišljavanjem raščišćuje put ka cilju: ovladavanju srodnim jezikom.

\section{O hrvatsko-ukrajinskoj jezičnoj homonimiji}

Nakon razmatranja hrvatsko-ruske prelazimo na razmatranje hrvatsko-ukrajinske međujezične homonimije.

Hrvatski i ukrajinski srodni su i sintetični jezici, pa je međujezična homonimija, kada je o takvim jezicima riječ, obvezna pojava. Radi boljeg razumijevanja međujezičnih homonimnih pojava u njima potrebno je poznavati njihove fonološke sustave.

Kada je riječ o broju fonema u suvremenomu ukrajinskome standardnom jeziku, danas se uglavnom ustalilo mišljenje da ih ima 38: vokalnih 6 i suglasničkih 32.

A kada je riječ o suvremenomu hrvatskome standardnom jeziku, uglavnom je prihvaćeno da postoje 32 fonema: 6 vokalnih, slogotvorni /r/ i 25 suglasničkih, među kojima i neslogotvorni sonorni /r/. (Neki ne prihvaćaju postojanje dvoglasnog fonema /'è/ - refleks dugoga jata, nego na mjestu bivšega dugoga jata vide foneme /je/, po čemu bi u suvremenomu hrvatskome standardnom jeziku bio 31 fonem.)

Važno je istaknuti da se - od 6 ukrajinskih vokalnih fonema - nijedan ne tretira fonemom srednjega reda.

Premda nema potpune podudarnosti u vezi s pitanjem kojega je reda fonem /a/, ipak se može reći da je općeprihvaćeno da su u suvremenomu ukrajinskome standardnom jeziku vokalni fonemi:

prednjega reda: /i/

stražnjega reda: /u/

$/ \mathrm{y} /$

/e/

/o/

$/ \mathrm{a} /$

pri čemu su /u/ i /o/ labijalizirani.

Dalje treba upozoriti na to da se - s obzirom na diobu vokalnih fonema po visini - među visokim fonemima prednjega reda razlikuju dvije razine, pa postoje:

prednji visoki /i/

stražnji visoki /u/

prednji sniženi visoki /y/

prednji srednji /e/

stražnji srednji /o/

stražnji niski /a/

Ukrajinski je vokalni fonem /y/ (u ukrajinskoj mu je ćirilici grafem slovo $u$, ali u pojedinim slučajevima i slovo $i$ ) na mjestu bivših dvaju vokalnih fonema: /i/ i /y/; njegovi se ostvaraji ne podudaraju s ostvarajima nijednoga od njih, a ispred sebe ne izaziva palatalizaciju, pa je tako u ukrajinskome danas, na primjer, i книгa/knyga $([\mathrm{n}]$, a ne [n'] = knjiga), i нива/nyva $([\mathrm{n}]$, a ne [n'] = njiva), i слива/slyva ([ł], a ne [l'] = šljiva (u ukrajinskome su /n/ i /l/ zubni, a ne alveolarni), i сила/syla = sila, i cup/syr = sir, i риба/ryba = riba.

Ukrajinski je vokalni fonem /i/ (u ukrajinskoj mu je ćirilici grafem slovo $i$ ) na mjestu bivših vokalnih fonema: jata /ě/ i starih /e/ i /o/ u zatvorenome slogu; na početku riječi u starim ukrajinskim riječima, u stranim riječima, a ispred sebe izaziva palatalizaciju. U po- 
ložaju poslije [j] (/j/) uvijek se bilježi grafemom zajedničkim za foneme /j/ i /i/ - slovom $\ddot{i}$, kao, npr., u riječi Украӥна = Ukrajina.

\section{Primjedbe:}

1. Navodeći u kosim zagradama foneme i u uglatima njihove ostvaraje, latinično slovo ipsilon y upotrebljavamo za označavanje: (1) i staroga slavenskoga srednjeg visokoga/y/, (2) i današnjega ukrajinskog prednjega sniženoga visokog /y/, i njegovih ostvaraja [y], (3) i današnjega ruskog srednjega visokog [y] (kao ostvaraja fonema /i/, ili kao ostvaraja fonema /y/). Ostvaraji ukrajinskoga /y/ zvuče drugačije od ruskoga [y], ali budući da ukrajinska opozicija /i/ : /y/ "podsjeća" na opoziciju [i] : [y] u ruskome, takvo je označavanje triju pojavnosti istim slovom - vjerojatno se podudaraju (1) i (3) - danas uobičajeno. (Postoje, već je rečeno, dva gledanja: 1. da je [y] u ruskome danas alofon fonema /i/ i 2. da postoje fonemi /i/ i /y/.)

2. Vidi se da i hrvatski i ukrajinski na mjestima bivših fonema /i/, /y/ ostvaruju jedan fonem: u hrvatskome je to /i/ (ostvaraji su mu "mlitaviji" od ostvaraja ukrajinskoga fonema /i/), u ukrajinskome je to /y/ (upravo zato što ukrajinski i danas, iz drugih - navedenih razloga ima opoziciju /i/ : /y/, ostvaraji su ukrajinskoga fonema /i/ obično nešto viši i više prednji od ostvaraja hrvatskoga /i/).

U nenaglašenim pozicijama u suvremenomu ukrajinskome standardnom jeziku dolazi do neutralizacije fonemā /y/ i /e/ (grafem mu je slovo e) i u zvučanju u području [y] (bilježi se $\left[\mathrm{y}^{\mathrm{e}}\right]$ ), i u zvučanju u području [e] (bilježi se [e $\left.\mathrm{e}^{\mathrm{y}}\right]$ ).

U vezi s redukcijom (skraćivanjem) vokala ima jedna pojava karakteristična za ukrajinski jezik: u određenim se pozicijama nenaglašeni vokali [i] i [u] izgovaraju kao neslogotvorni [i] i [u], kada se akustički izjednačuju s (određenim) alofonima fonema /j/ i /v/, što ukrajinski pravopis prati, pa se takvi neslogotvorni alofoni vokala pišu ćiriličnim slovima $\check{u}$ (u hrv. lat.: $j$ ) i $в$ (u hrv. lat.: v) (tako da se u istoj rečenici - prema tome u kakvom su fonetskom okruženju - može naći $i$ i $\breve{u}, y(u$ hrv. lat.: $u$ ) i $в$ ). Evo nekoliko primjera, uzetih iz Украинская грамматика, 1986:12: Максим ide / Maksym ide (= Maksim ide), Ганна ŭде / Ganna jde (= Ganna ide); овес $і$ жито / oves $i$ žyto (= zob i raž), жито й овес / žyto j oves; yчuти - вчити / ис̌yty - vс̌yty (= učiti), наш учитель - наша вчителька / naš ис̆ytel' - naša včytel’ka (= učiteljica).

Za sustav je vokalnih fonema suvremenoga ukrajinskoga standardnog jezika karakteristično, dakle, nepostojanje fonema srednjega reda, nesimetričnost prednjega i stražnjega reda po visini, pozicije neutralizacije, s jedne strane, vokalnih fonema /y/ i /e/ i, s druge, vokalnih fonema /i/ i /u/ i suglasničkih fonema /j/ i /v/. (Postoji i pojava, izrazito razvijena u nekim govorima, a manje uočljiva u standardnome jeziku: u nekim se pozicijama nenaglašeni ostvaraji fonema /o/ približavaju ostvarajima fonema /u/.)

Za sustav je vokalnih fonema suvremenoga hrvatskoga standardnog jezika karakteristično: postojanje (jednoga) fonema srednjega reda, postojanje (jednoga) dvoglasnog fonema, u vezi s kojim je i nesimetričnost prednjega i stražnjega reda po visini (ili: simetričnost vokala prednjega i stražnjega reda ako se ne prihvati postojanje dvoglasnoga fonema), ne- 
postojanje pozicija neutralizacije (međusobno vokalnih, ili vokalnih i suglasničkih) fonema, postojanje likvidnog suglasnika [r] u funkciji slogotvornog fonema /r/.

Već je rečeno da su u suvremenomu ukrajinskome standardnom jeziku 32 suglasnička fonema: 22 nepalatalizirana (tvrda), 9 palataliziranih (mekih) i 1 palatalni. To su fonemi (redoslijedom slova ukrajinskoga alfabeta):

nepalatalizirani (tvrdi): /b/ (б), /v/ (в), / / (г), /g/ (г), /d/ (д), /̌̌/ (ж), /dž/ (дж), /z/ (з), / dz/ (дз), /k/ (к), /1/ (л), /m/ (м), /n/ (н), /p/ (п), /r/ (р), /s/ (с), /t/ (т), /f/ (ф), /h/ (х), /с/ (ц), $/ \check{\mathrm{c}} /($ (ч), $/ \check{\mathrm{s}} /($ (ш);

palatalizirani (meki): /d'/,/z'/,/dz'/, /l'/, /n'/,/r'/,/s'/,/t'/, /c'/ (u ukrajinskim se fonetikama palataliziranost bilježi "crticom" iznad sa strane, a polupalataliziranost "zarezom" iznad sa strane);

palatalni: /j/.

\section{Primjedbe:}

1. Nepalatalizirani suglasnčki fonemi koje ima ukrajinski, a nema suvremeni hrvatski standardni jezik:

$\mid \gamma /$ - tjesnačni faringalni zvučni (hrvatski ga govornici “prepoznaju” kao [g] ili [h]), odgovara hrvatskomu /g/;

/dz/ - zvučna zubna afrikata (hrvatski ga govornici imaju "na periferiji” sustava suglasničkih fonema, pa ga lako ostvaruju);

/1/ i /n/ - već je rečeno da su zubni, a ne alveolarni; u fonetskoj transkripciji ostvaraje fonema /1/ bilježimo [1].

2. Palatalizirani suglasnički fonemi koje ima ukrajinski, a nema suvremeni hrvatski standardni jezik:

/d'/,/z'/,/dz'/,/r'/,/s'/, /t'/,/c'\%.

Ako se ovim sedam palataliziranim fonemima, koje nema hrvatski jezik, dodaju /l'/ i /n'/ (koje - vrlo bliske - hrvatski jezik ima), uočava se jedna od bitnih crta sustava suglasničkih fonema suvremenoga ukrajinskoga standardnog jezika - postojanje devet parova nepalataliziranih / palataliziranih suglasničkih fonema.

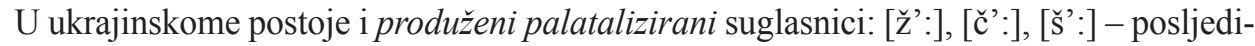
ca (umjesto jotacije) bivše progresivne asimilacije, karakteristične za ukrajinski jezik, npr., u riječima: роздоріжжя / rozdorižžja = raskršće, обличчя / oblyččja = lice, затишия / zatyššja = zatišje, koje većina ukrajinskih fonetičara ne smatra posebnim fonemima.

3. Uočava se još jedna karakteristika - postojanje četverokuta:

/c/ /c'/

$/ \mathrm{dz} / / \mathrm{dz} /$

4. Za ukrajinski je karakteristično da su i /v/ i /f/ uvršteni u dvousnene (a ne zubno-usnene) foneme.

Također je karakteristično da se /v/ u određenim pozicijama ostvaruje kao neslogotvorni [un], a i kao [u], što ukrajinski pravopis prati, pa se, osim slovom 6 , taj fonem bilježi i slovom $y$. 
5. Za razliku od ruskoga i bjeloruskoga, u suvremenomu standardnome ukrajinskom jeziku krâj riječi / iskaza nije pozicija neutralizacije suglasnika po zvučnosti / bezvučnosti (kao što nije ni u hrvatskome standardnom (temeljenome na novoštokavštini), ni u čakavskome narječju, ali jest u kajkavskome).

U suvremenomu standardnome hrvatskom jeziku, rečeno je, 25 je suglasničkih fonema: kao i u ukrajinskome, postoji palatalni /j/, ali i palatalni /ćc/,/d/, /lj/,/nj/, pa je za suvremeni standardni hrvatski karakterističan četverokut:

$|\check{c} /| \dot{c} /$

/džl/ /d/

(kakav ima i poljski jezik, od čega ukrajinski ima samo lijevu stranu).

U hrvatskomu nije - kako jest u ukrajinskome - položaj ispred [i] (/i/) pozicija obveznog pojavljivanja palataliziranih (ili polupalataliziranih) suglasnika.

$\mathrm{U}$ hrvatskomu postoje dvije ravnopravne pozicije neutralizacije suglasničkih fonema (šumnika) po zvučnosti: bezvučni + zvučni $=$ zvučni + zvučni, zvučni + bezvučni $=$ bezvuč$\mathrm{ni}+$ bezvučni, a u ukrajinskome - čime se ističe među slavenskim jezicima - samo prva od njih: bezvučni + zvučni = zvučni + zvučni (jer odnos zvučni + bezvučni ostaje nepromijenjen, osim: u prefiksima i u slučaju $/ \gamma /$ ispred bezvučnih u sredini riječi (ne i u infinitivima)).

O pozicijama mijenjanja ostvarajā fonemā izazvanih susjedstvom fonemā različitih po mjestu artikulacije (kao, npr., u hrvatskom: iščašiti, današnji) ovdje ne ćemo govoriti.

I suvremeni ukrajinski standardni jezik (kao što je bilo rečeno za ruski) ima dinamički naglasak, i već po tome znači da potpune hrvatsko-ukrajinske međujezične homonimije homofonije (kao i kada je bila riječ o hrvatsko-ruskoj) ne može biti.

Ali ako zanemarimo nejednakost ostvaraja - modelski - istih (ili približno istih) fonema, ako nejednake, ali slične, uvijek analogne foneme (npr. /y/ i / / /) naučimo "čuti" kao "takve" svoje (kao /i/ i /g/), ako postfiks -ca/-cb primamo kao analog morfemu satelitu se, ako zanemarimo i različito mjesto naglaska (koje govornika hrvatskoga jezika "ne zbunjuje", ne kvari mu "jasno prepoznavanje riječi" ukrajinskog jezika), onda moramo uočiti međujezičnu homonimiju koja se zasniva na međujezičnoj polisemiji srodnih jezika. Evo primjera homonimije - homografije:

... друга година ...(година [үodyna] $\mid$ godina $)=\ldots d v a($ su) sata ...(druga (je) ura ...)

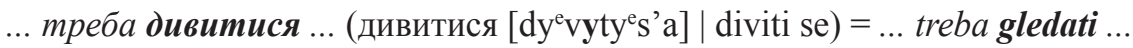

... дерев'яна домовина ... (домовина [domovyna] | domovina) $=$... drveni lijes ...

... зріло жсито ... (жито [žўto] | žito) = ... zrela raž...

... велика журбба ... (журба [žurba] | žurba) = ... velika tuga, sjeta ...

... там не можна пролазити ... (пролазити $\left[\right.$ prolazyetye $\left.^{\mathrm{e}}\right] \mid$ prolaziti) $=\ldots$ tamo se ne smije / ne može provlačiti; propuzati ...

... моя дружсина ... (дружина [družyna] | družina) = .. moja žena, supruga; moj тиz̆, suprug; (hist.) kneževa družina ...

(Hrvatski govornik može, npr., ukrajinsku riječ миршавий [myršavy ${ }^{\mathrm{i}}$ ] (na kraju je $n$ eslogotvorni [i]) shvatiti kao samo malo "iskrivljenu" hrvatsku mršav(i), što daje međujezični homonimski par:

... мириавий чоловік ... (миршавий $\mid \operatorname{mršav}(\mathrm{i}))=\ldots$ neugledan(ni) muškarac ...) 
Medujezična homonimija srodnih jezika može se zasnivati i na međujezičnoj polisemiji gramatičkih morfema. Evo primjera s polisemičnošću sufiksa: čovjek...

... вона теж людина ... (людина [l'udyna] | ljudina) $=$... ona je također / $i$ ona je

(Ako hrvatski govornik zna pravilo o prijelazu bivših /o/ i /e/ u zatvorenome slogu u /i/, ali ne poznaje danu riječ, u ukrajinskoj: жжінка / žinka (= žena, ženska osoba; žena, supruga) nedvojbeno će "prepoznati” hrvatsku: ženka.)

Medujezična homonimija srodnih jezika može se zasnivati i na različitim fonetskim (i morfofonemskim) zakonitostima koje s vremenom nastaju. Evo primjera s ukrajinskim riječima u kojima je ostvaren prijelaz bivšeg /o/ u zatvorenome slogu u /i/ (u kombinaciji su riječi samo slavenskoga te slavenskoga i neslavenskoga porijekla):

... мій бік ... (бік $\mid$ bik $)=\ldots$ moj bok ...

... иирокий брід ... (брід $\mid$ brid $)=\ldots$.. širok(i) gaz (gdje se rijeka može pregaziti) ...

... жовтий дім ... (дім $\mid \operatorname{dim})=\ldots$ žuta kuća, zgrada ...

(Homografi su ukrajinske riječi i sa slovom $u$ i sa slovom $i$. Što se izgovora tiče, u dim se dobro čuje palatalizirani [d'] ispred [i], ali to ne narušava "prepoznavanje" te riječi kao riječi dim.)

... білий кіт ... (кіт | kit) = .. bijel(i) mačak ...

... високий стіл ... (стіл $\mid$ stil $)=\ldots$ visok(i) stol ...

(U стіл se dobro čuje palatalizirani [t'], ali to ne ometa "prepoznavanje" te riječi kao riječi stil.)

Primjeri homonimskih parova koji se temelje na hrvatskom refleksu bivšega jera /ь/:

...чорний пас ... (пас | pas - ne: pâs $)=\ldots$ crn $($ i) pojas ...

... красивий палац ... (палац | palac) = ... lijepa palača ...

Drugi primjeri homonimskih parova u koje ulaze riječi neslavenskoga i slavenskoga ili samo neslavenskoga porijekla:

... моя майка ... (майка $\mid$ majka) = .. moja majica, potkošulja ...

... периий кат ... (кат $\mid$ kat $)=$... prvi krvnik ...

(Ukrajinska je riječ kam došla iz poljskoga jezika, hrvatska kat - iz turskog.)

U ovome tekstu nismo posebno razmatrali homonimiju između punoznačnih (samostalnih) i gramatičkih riječi, između gramatičkih riječi međusobno i, u tome okviru, izdvojeno homonimiju prijedloga, a s time u vezi i homonimiju prefiksa. Poseban je zadatak da se obradi medujezična - hrvatsko-ukrajinska - homonimija prefiksa i sufiksa. To su zadaci koji čekaju svoju obradu.

\section{Na kraju}

Medujezična homonimija srodnih jezika obvezna je pojava. Ona je njihova pratilja i dokaz njihove srodnosti - i to upravo homonimija: a) koja je posljedica bivše polisemije i b) koja je posljedica drugačijih fonetskih (i morfofonemskih) zakonitosti, što kasnije, nakon nekoga zamišljenog jedinstva, počinju razdvajati srodne jezike; c) medu srodnim je jezicima, kao što su sintetični slavenski jezici, prilično zastupljena homonimija koja se 
zasniva na homonimnosti nastavaka (što mi ovdje nismo obrađivali, npr.: ukr. gen. jedn. краю, dat. jedn. краєві (i краю) i hrv. dat./lok. jedn. kraju / (o) kraju, nom. množ. krajevi); d) homonimija koja je "posve slučajna" nije tipična za srodne jezike, ona je moguća među svim jezicima (ali u srodnima može biti češća zbog velike sličnosti ili podudarnosti fonema - njihovih ostvaraja - u njima).

Dakle, homonimija je između hrvatskoga, ruskoga i ukrajinskog jezika - stvarnost. I bez obzira na to što jezik u svojem ostvarenju, u govoru, rijetko dovodi u vezu riječi ovako, kako su dovedene u vezu u ovome članku, što postoji kontekst, tj. što je govor pun redundancije koja treba da sačuva (i najčešće čuva) poruku, što postoji i (konkretno) vanjezično okruženje u trenutku govornoga čina, želi li govornik jednoga od triju razmatranih jezika savladati drugi - mora je biti svjestan i mora je prepoznavati.

Ta se pojava može nazivati, i najčešće se naziva, lažni prijatelji, ali mi u tome nazivu ne vidimo lingvistički termin, nego sintagmu-sliku, opis dojma, impresionistički pristup jezičnoj pojavi koja svoj naziv - unutar jezika - već ima.

Lažni prijatelji znači - "prepoznavanje" u drugom jeziku, dakle tobožnje, krivo. A nema ga bez sličnosti: manje, veće ili potpune. Bitno je da je tolika da automatski dovodi do tog "prepoznavanja". A budući da je homonimija (unutar jednog jezika) istost na planu izraza i različitost na planu sadržaja, onda je to, premda i unutar širih granica kada je riječ o srodnim jezicima, također homonimija, samo međujezična homonimija, s nekim dodatnim činjenicama u odnosu na homonimiju, na koje i upozorava pridjev međujezična. 